\title{
MISTAKES IN THE USAGE OF ANATOMICAL TERMINOLOGY IN CLINICAL PRACTICE
}

\author{
David Kachlika, ${ }^{\mathrm{a}, *}$, Ivana Bozdechova ${ }^{\mathrm{c}}$, Pavel Cech ${ }^{\mathrm{d}}$, Vladimir Musil ${ }^{\mathrm{e}, \mathrm{f}}$, Vaclav Baca ${ }^{\mathrm{a}, \mathrm{b}}$ \\ a Department of Anatomy, Third Faculty of Medicine, Charles University in Prague, Ruska 87, Praha 10, 100 00, Czech \\ Republic \\ ${ }^{b}$ Department of Medicine and Humanities, Faculty of Biomedical Engineering, Czech Technical University in Prague, \\ Kladno, Czech Republic \\ c Institute of Czech Language and Theory of Communication, Faculty of Arts, Charles University in Prague, Czech Republic \\ ${ }^{d}$ Department of History of Medicine, Third Faculty of Medicine, Charles University in Prague, Czech Republic \\ e Centre of Scientific Information, Third Faculty of Medicine, Charles University in Prague, Czech Republic \\ ${ }^{f}$ Institute of Information Studies and Librarianship, Faculty of Arts, Charles University in Prague, Czech Republic
}

Received: September 12, 2008; Accepted (with revision): January 10, 2009

Keywords: Anatomy/Terminology/Nomenclature

Background: Anatomical terminology serves as a basic communication tool in all the medical fields. Therefore Latin anatomical nomenclature has been repetitively issued and revised from 1895 (Basiliensia Nomina Anatomica) until 1998, when the last version was approved and published as the Terminologia Anatomica (International Anatomical Terminology) by the Federative Committee on Anatomical Terminology.

Methods and results: A brief history of the terminology and nomenclature development is mentioned, along with the concept and contributions of the Terminologia Anatomica including the employed abbreviations. Examples of obsolete anatomical terms and their current synonyms are listed. Clinicians entered the process of the nomenclature revision and this aspect is demonstrated with several examples of terms used in clinical fields only, some already incorporated in the Terminologia Anatomica and a few obsolete terms still alive in non-theoretical communication. Frequent mistakes in grammar and orthography are stated as well.

Conclusion: Authors of the article strongly recommend the use of the recent revision of the Latin anatomical nomenclature both in theoretical and clinical medicine.

\section{ABBREVIATIONS}

BNA - Basiliensia Nomina Anatomica

BR - Birmingham Revision

FCAT - Federative Committee on Anatomical Terminology

FICAT - Federative International Committee on Anatomical Terminology

INA - Jenaiensia Nomina Anatomica

IANC - International Anatomical Nomenclature Committee

IFAA - International Federation of Associations of Anatomists

NA - Nomina Anatomica

PNA - Parisiensia Nomina Anatomica

TA - Terminologia Anatomica

TH - Terminologia Histologica

\section{BACKGROUND}

All scientific fields use terminology as a basic tool for communication and recording. Anatomy can be considered as the first exact medical field dating back to the ancient period and that is why its terminology stems from
Greek and later Latin. This principle has endured until now and serves as a base for anatomical nomenclature. The aim of this article is to show the current situation of the anatomical terminology which is used both during the study of medicine and in the communication among specialists from all medical branches. Using terms that were omitted in newer revisions of the Latin anatomical terminology, is currently very common. Who is responsible for the inappropriate use of terminology? Clinicians, who are not well informed about new versions of the anatomical nomenclature? Or is the nomenclature itself insufficient? And as a result, the clinicians introduce their own terms for some anatomical structures.

Firstly, it is necessary to define several terms. Anatomy uses a special vocabulary, but anatomical terminology and nomenclature must be distinguished unlike in many other medical fields. Terminology is a system of terms used in a certain scientific branch. Nomenclature is a standardized system of precisely defined terms, set according to certain classification principles and containing terms created within the scope of terminology. The nomenclature is usually assented by a special commission of the appropriate scientific field. 
Table 1. The comparison of the obsolete terms from previous nomenclature or clinical use and the recently valid Latin anatomical terms.

\begin{tabular}{|l|l|}
\hline Obsolete term & Valid term in TA \\
\hline Fossa ischiorectalis & Fossa ischioanalis \\
\hline Centrum tendineum perinei & Corpus perineale \\
\hline Sutura frontalis & Sutura frontalis persistens; Sutura metopica \\
\hline Ramus descendens nervi hypoglossi & Radix superior ansae cervicalis \\
\hline Os naviculare (Manus) & Os scaphoideum \\
\hline Ligamentum transversum carpi & Retinaculum musculorum flexorum \\
\hline Arteria anonyma & Truncus brachiocephalicus \\
\hline Arteria hypogastrica; Arteria ilica interna & Arteria iliaca interna \\
\hline Arteria mammaria interna & Arteria thoracica interna \\
\hline Chorda uteroinguinalis & Ligamentum teres uteri \\
\hline Fontanella & Fonticulus \\
\hline Plexus solaris & Plexus coeliacus \\
\hline Ventriculus (Systema digestorium) & Gaster \\
\hline Introitus vaginae & Ostium vaginae \\
\hline Verumontanum & Colliculus seminalis \\
\hline Epipharynx; Nasopharynx & Pars nasalis pharyngis \\
\hline Oropharynx & Pars oralis pharyngis \\
\hline Laryngopharynx; Hypopharynx & Pars laryngea pharyngis \\
\hline
\end{tabular}

Table 2. Terms and their abbreviations and symbols in TA.

\begin{tabular}{|l|l|}
\hline Term & Abbreviation or symbol \\
\hline Nervi craniales & Nervus I-XII \\
\hline Costae & Costa I-XII \\
\hline Vertebrae & C1-7, T1-12, L1-5, S1-5, Col-3 \\
\hline Segmenta bronchopulmonalia & SI-10 \\
\hline Bronchi segmentales & Bl-10 \\
\hline Strata isocorticis & Lamina I-VI \\
\hline Regiones hippocampi proprii & Regio I-IV; CAI-4 \\
\hline Laminae columnae posterioris & Lamina I-X \\
\hline parts of cerebellum - vermis & I-X (VII A-B, VIII A-B) \\
\hline parts of cerebellum - hemispherae & H I-X (H VII A-B, H VIII A-B) \\
\hline
\end{tabular}

Table 3. The clinical terms (or their definition) incorporated in TA and its extensions.

\begin{tabular}{|l|l|}
\hline Clinical terms & Valid Latin anatomical equivalents \\
\hline Cooper's ligament & Ligamentum pectineum \\
\hline Calot's triangle & Trigonum cystohepaticum \\
\hline Thomson's ligament & Tractus iliopubicus \\
\hline Bauhin's ileocaecal valve & Ostium ileale caeci \\
\hline $\begin{array}{l}\text { The part of the femoral vein proximal to the vena } \\
\text { profunda femoris opening }\end{array}$ & Vena femoralis communis \\
\hline $\begin{array}{l}\text { The last proximal valves in the end segment of the } \\
\text { vena saphena magna and the vena saphena parva }\end{array}$ & Valvula terminalis \\
\hline $\begin{array}{l}\text { The second last proximal valves in the end segment } \\
\text { of the vena saphena magna and the vena saphena parva }\end{array}$ & Valvula preterminalis \\
\hline Paturet's venous star; Cockett's venous star; Crosse & Confluens venosus subinguinalis \\
\hline Vena femoropoplitea & Extensio cranialis venae saphenae parvae \\
\hline Boyd's perforator & Vena perforans cruris paratibialis superior \\
\hline Cockett's perforators & Vena perforans cruris posterior superior, media et inferior \\
\hline Dodd's perforator(s) & Venae perforantes canalis adductorii \\
\hline
\end{tabular}




\section{RESULTS}

This year, 114 years have passed since the first anatomical nomenclature approval in Latin in the year 1895. The first traces of the nomenclature go back to the time of Hippokrates of Kós (circa 460-370 BC) in Greece. He introduced for example the term bronchus or peritoneum. Aristotle (Aristoteles, 384-322 BC) wrote of the diaphragma, pancreas or aorta. Rufus of Efesos (late 1st century $\mathrm{AD})$ published the first book concerning the terminology, entitled "On the naming of the parts of the body". Aulus Cornelius Celsus (25 BC-circa 50 AD) introduced sutura, patella or cartilago. Cladius Galenos of Pergamon (129 or 130-199 or 200) described many new parts of the body but avoided the use of terminology; nevertheless he introduced e.g. epiphysis and hypophysis, coccyx, tarsus, pylorus, aponeurosis or epididymis ${ }^{1}$. Andreas Vesalius Bruxellensis (Andreas van Wesel, 1514-1564), author of the first true anatomy atlas "De fabrica corporis humani libri septem" which replaced all the Greek and Arabic terms with Latin ones and initiated the usage of ordinal numbers for muscles, bones, blood vessels and nerves. In osteology alone, he included more than 700 structures ${ }^{2}$. Jacobus Sylvius (Jacques Dubois, 1478-1555) preferred descriptive terms and invented new terms for muscles, blood vessels and nerves (levator). Caspar (Gaspard) Bauhin (1560-1624) promoted new types of descriptive terms for muscles, based on their origins and insertions ${ }^{3}$. Johannes Jessenius (Ján Jesenský, 1566-1621) employed in his work "Anatomiae pragae anno MDC selenniter administrate historia" both an ordinary and descriptive approach in the terminology4.

The modern period brought an exorbitant mass of anatomical terms. Several terms were used as synonyms for the same structure but simultaneously one term could have been applied as a homonym for more structures. Eycleshymer counted 16 synonyms for "glandula pinealis" in 1917, e.g. "pineal body, parietal eye, penis cerebri or epiphysis" ${ }^{3}$. Friedrich Gustav Jakob Henle (1809-1885) and Joseph Hyrtl (1810-1894) tried to solve this problem and the latter published an explanatory book called "Onomatologia anatomica", which consists of a detailed linguistic analysis of 421 terms 5 .

The society of German-speaking anatomists (Anatomische Gesellschaft) issued the first Latin anatomical nomenclature in 1895 as the Basiliensia Nomina Anatomica (BNA). In 1903, the International Federation of Associations of Anatomists (IFAA) was founded and began to revise the nomenclature. In 1933, the Anatomical Society of Great Britain and Ireland published its own norm called Birmingham Revision (BR) and the Anatomische Gesellschaft edited a new revision, the Jenaiensia Nomina Anatomica (INA) in 1935. The International Anatomical Nomenclature Committee (IANC) was established by IFAA in 1936 and issued the first version of the Latin anatomical nomenclature accepted worldwide as the Parisiensia Nomina Anatomica (PNA). Due to accelerating research progress, further revisions were published as the Nomina Anatomica (NA): $2^{\text {nd }}$ to $6^{\text {th }}$ edition $(1961,1966,1977,1983,1989)$. The $4^{\text {th }}$ edi- tion of $N A$ was combined with the first Latin histological and embryological nomenclatures (Nomina Histologica, Nomina Embryologica). A new commission was nominated (The Federative Committee on Anatomical Terminology - FCAT; it later changed to Federative International Committee on Anatomical Terminology FICAT) in 1989 and for the time being the last revision was edited in 1998 as the Terminologia Anatomica, subtitled International Anatomical Terminology $(T A)^{6.8}$.

The first real steps of clinicians were two consensus documents, approved in 2001 and 2004 by the International Union of Phlebology (IUP), IFAA, and FICAT which revised and extended the nomenclature of the lower extremity veins ${ }^{9-12}$. The last enterprise of FICAT is the Terminologia Histologica (TH), subtitled International Terms for Human Cytology and Histology ${ }^{13}$.

The official terms of the $T A$, used in this article, are written in italics and with quotation marks; the unofficial, old or incorrect terms are in normal font and with quotation marks.

$T A$ (including the CD-ROM) comprises the 7635 Latin anatomical terms which are considered as standardized. They are accompanied by the terms currently used in the English-speaking countries. Each pair of terms owns a unique identification number. Indentation and headings are used to indicate the relation between the two following terms. The list of Latin terms is recommended to serve as a base for revising the national anatomical nomenclatures. FCAT kindly invites constructive comments and considerations for future editions in the preface of TA. They should be sent by e-mail to leser.service@thieme.de or by mail ${ }^{6,14}$.

Some terms have one synonym, e.g. "substantia gelatinosa; lamina spinalis II", "lamina visceralis pericardii; epicardium", "plexus hypogastricus inferior; plexus pelvicus", "arteria splenica; arteria lienalis" or rarely two, e.g. "glandula vesiculosa; glandula seminalis; vesicula seminalis" or "myelencephalon; medulla oblongata; bulbus". In case of more synonyms, FCAT highly recommends the first one.

We start with general anatomy. The terms used to describe the planes, sections, and directions are very old and stated by all versions of the nomenclature. But due to the inclination of INA towards the veterinary anatomy, many terms have been erroneously applied to the human body by simply changing the position from vertical to horizontal to unify the human and animal anatomy. PNA brought the definitive replacement of terms for the direction ("cranialis-caudalis, ventralis-dorsalis") with terms for the position ("superior-inferior, anterior-posterior"), i.e.. "arteria mesenterica superior" instead of "arteria mesenterica cranialis" (which remained for the veterinary anatomy only). Except the nervous system, the term "cranialis" is used only to describe the relation to the skull ("cranium") - "pars intracranialis arteriae carotidis internae"), the term "caudalis" in "retinaculum caudale" in hypodermis above the coccyx, "ventralis" in some small muscles of the trunk and "dorsalis" in case related to the dorsum of an organ (hand, foot, tongue, penis). In brain, due to its flexion during the development anteriorly, the original terms do not designate the appropriate directions, e.g. there are 
both "nuclei anteriores et posteriores" and "nuclei ventrales et dorsales" in the diencephalon.

An example from the lymphatic system can demonstrate the successive change of the term throughout various revisions of the nomenclature: $B N A$ - "lymphoglandula", INA - "lymphonodus", $P N A$ - "nodus lymphaticus", TA - "nodus lymphoideus" (with non-preferred valid synonyms "nodus lymphaticus; lymphonodus"), or of the term from nervous system: $B N A$ - "nervus acusticus", INA - "nervus statoacusticus", $P N A$ - "nervus stato-acusticus", $N A$ and $T A$ - "nervus vestibulocochlearis".

Other examples of the obsolete terms from previous nomenclature or from clinical use and their valid Latin anatomical terms, used in $T A$, are listed in the Table 1.

An interesting phenomenon is an extensive introduction of new terms in $T A$, reflecting the rapid development of some scientific branches. This is seen especially in the nervous system with 1082 new items when compared to $P N A$. This includes newly described nuclei (e.g. "sagulum" in lateral part of the tegmentum pontis), various groups of cells "aggregationes cellularum chemergicarum" - 33 terms of cell groups producing neuromediators), pathways, tracts, etc.

$T A$ introduced abbreviations and symbols, placed behind the term in square brackets using Arabic and Roman ciphers and upper case letters - see Table 2. The abbreviation " $\mathrm{Th}$ " for the thoracic vertebrae was simplified to mere " $T$ ".

Not only were whole words and terms changed, but also the orthography. The diphthong - ae - has been successively simplified to - e - (e.g. instead of "praeputium”, "peritonaeum", "aequator" we use "preputium", "peritoneum", and "equator"). As for the grammar, many errors can be found in current journals concerning problems with declension, e.g. "vasa femoralis" instead of "vasa femoralia" or "vasa vasora; vasa vasorium" in place of "vasa vasorum". Frequently, the authors of articles themselves introduce errors, for example "nodus sinuatrialis" is sometimes written as "nodus sinoatrialis", or clinical terms for examination should be used as sinuscopy and sinutomy and not sinotomy a sinoscopy, because they are both derived from the term "sinus". The adjective "inguinalis" is related to "inguen" (groin) and must not be written as "inquinalis". Often used term "arteria carotica" shall be replaced with "arteria carotis" (with plural term "arteriae carotides"). Spelling mistakes are represented by for example "siphon caroticum", which is different from the English translation carotid syphon, or by terms "ileofemoralis" or "ilicocavalis" which should be written as "iliofemoralis" and "iliocavalis", since they have been derived from the term "iliacus". An often used term "musculus dilator pupillae", obviously influenced by English, should be omitted and replaced with "musculus dilatator pupillae".

However, grammar mistakes are also present in the $T A$. We present two examples: "systema conducente cordis" the middle word should be written as "conducens" - and "lineae distractiones cutis" - the middle word should be stated as "distractions"

Thanks to the clinical anatomists, several clinical terms have been incorporated in the anatomical nomen- clature, either in $T A$ or in its extensions ${ }^{12}$, see Table 3. There are discussions concerning including further terms, such as "articulatio femoropatellaris", "sinus venosus sclerae", and "ductus nasolacrimalis" 16,17 or arguing about the definition of the extent of the "canalis analis" 18 and the definition of the term "fascia" in various parts of the body - in hypodermis of abdomen and perineum, thoracic and abdominal cavity, or in lesser pelvis ${ }^{19-22}$.

However, many other important structures for which the usage is fundamental for clinicians still remain unnoticed by the $T A$, e.g. "arteria femoralis communis", "tuberculum vastoadductorium", "fissura scalenorum". A few examples of the variant anatomy are already incorporated in $T A$ (stated in parentheses), such as "processus supracondylaris humeri", "os centrale”, "arteria brachialis superficialis", but many clinically important variants, such as "arteria lusoria”, "corona mortis Hesselbachi”, "arteria renalis accessoria”, "septum styloideum”, "Killian's triangle", "lobus venae azygos" etc. are still missing and unjustly neglected. Moreover, the incorrect used form of the term "lobus venae azygos" should be replaced with the "lobus venae azygoi", according to the Greek grammar.

For the description of the caudal end of the spinal cord, the terms "conus" and "epiconus" are frequently used in neurology. Unfortunately, only the term "conus medullaris" is a part of TA.

In radiological articles, concerning the distal part of humerus, a term "capitellum" is disposed with different meanings. It is applied either to the "capitulum humeri", then it should be omitted and replaced with the latter, or to the ossification center in the mass of the "capitulum humeri" and not only to its articular surface ${ }^{23}$.

Finally, ridiculous terms are components of the nomenclature ("hippocampus, oliva, amygdala") but a really startling paradox is the usage of the term "substantia innominata" of Reichert in TA. Joseph Hyrtl already expressed his amazement over such terms in $1880^{15}$.

For further details and eponyms, see publications concentrating on the terminology, nomenclature, and $T A^{8,14,24-28}$, supported by grants of the Czech Ministry of Education, Youth and Sports - www.anatomickenazvoslovi.cz.

\section{CONCLUSION}

The $T A$ has not found its way among the medical specialists in the Czech Republic and thus has remained well-known only to the anatomists. We notice this sad and unpleasant situation in many translations of medical books in the Czech language after 1998. There are several exceptions in original Czech anatomical atlases and a few translated ones ${ }^{29-38}$. It is especially non-fiction books which suffer from this absence of information. This article should recall the existence of the $T A$ and reiterate its fundamental importance. It should also draw attention to several principle changes and frequent mistakes in the Latin anatomical nomenclature.

As for the future of the nomenclature, FICAT prepares to issue the Terminologia Embryologica and to revise the 
$T A$. All these activities are aimed at one goal: simple and unambiguous communication in our increasingly globalized world.

Authors of the article strongly recommend to use the recent revision of the Latin anatomical nomenclature, either in oral or in written form, both in theoretical and clinical medicine.

\section{REFERENCES}

1. O'Rahilly R. Anatomical terminology, then and now. Acta Anat 1989; 134:291-300.

2. Sakai T. Historical evolution of anatomical terminology from ancient to modern. Anat Sci Int 2007; 82:65-81.

3. Zoske H. Die Osteologie Vesals: Untersuchungen zur Geschichte der anatomischen Nomenklatur. Hannover: Schmorl \& v. Seefeld; 1951.

4. Jessenius J. Průběh pitvy jím slavnostně provedené v Praze L.P. MDC, k níž byl přičleněn traktát o kostech. Praha: Nakladatelství Karolinum; 2004.

5. Hyrtl J. Onomatologia anatomica. Geschichte und Kritik der anatomischen Sprache der Gegenwart mit besonderer Berücksichtigung ihrer Barbarismen, Widersinnigkeiten, Tropfen und grammatikalischen Fehler. Wien: Wilhelm Braumüller; 1880.

6. FCAT. Terminologia anatomica. Stuttgart: Thieme Verlag; 1998. (CD-ROM).

7. Hahn von Dorsche H. Die Nomenklaturen der Anatomen. Anat Anz 1981;150:11-43.

8. Kachlik D, Baca V, Bozdechova I, Cech P, Musil V. Anatomical Terminology and Nomenclature: Past, Presence and Highlights. Surg Rad Anat 2008; 30:459-66.

9. Caggiati A, Bergan J, Gloviczki P, Eklof B, Allegro C, Partsch H. International Interdisciplinary Consensus Committee on Venous Anatomical Terminology: Nomenclature of the veins of the lower limb: extensions, refinements, and clinical application. J Vasc Surg 2005; 41:719-24.

10. Caggiati A, Bergan J, Gloviczki P, Jantet G, Wendell-Smith CP, Partsch H. Nomenclature of the veins of the lower limbs: An international interdisciplinary consensus statement. J Vasc Surg 2002; 36:416-22.

11. Kachlík D, Pecháček V, Bača V, Musil V. Information on the chang es in the revised anatomical nomenclature of the lower limb veins. Biomed Pap Med Fac Univ Palacky Olomouc Czech Repub. 2009, 153 - submitted.

12. Kachlík D, Pecháček V, Báča, Musil V. Nové názvosloví povrchových žil dolní končetiny. Prakt Flebol 2008; 17:4-12.

13. FICAT. Terminologia histologica: international terms for human cytology and histology. Philadelphia: Wolters Kluwer. Lippincott Williams \& Wilkins; 2008.

14. Kachlík D, Bozděchová I, Čech P, Musil V, Báča V. Deset let nového anatomického názvosloví. Čas Lék čes 2008; 5:287-94.
15. Marečková E, Šimon F, Červený L. On the new anatomical nomenclature. Ann Anat 2001; 183:201-7.

16. Krmpotić-Nemanić J, Vinter I. Missing and incorrect terms in terminologia anatomica (1998). Ann Anat 2003; 185:387-8.

17. Krmpotić-Nemanić J, Vinter I. Incorrect terms in Terminologia anatomica. Ann Anat 2003; 185:195-6.

18. Wendell-Smith CP. Anorectal nomenclature: fundamental terminology. Dis Colon Rectum 2000; 43:1349-58.

19. Wendell-Smith CP. Fascia: an illustrative problem in international terminology. Surg Radiol Anat 1997; 19:273-7.

20. Skandalakis PN, Zoras O, Skandalakis JE, Mirilas P. Transversalis, endoabdominalis, endothoracic fascia: who's who? The American Surgeon 2006; 72:16-8.

21. Ercoli A, Delmas V, Fanfani F, Gadonneix P, Ceccaroni M, Fagotti $A$, et al. Terminologia Anatomica versus unofficial descriptions and nomenclature of the faciae and ligaments of the female pelvis: A dissection-based comparative study. Am J Obstet Gynecol 2005; 193:1565-73.

22. Otčenášek M, Báča V, Krofta L, Feyereisl J. Endopelvic Fascia in Women: Shape and Relation to Parietal Pelvic Structures. Obstet Gynecol 2008; 111:622-30.

23. Mulligan M. International anatomical terminology. Skeletal Radiol 2006;33:717-8

24. Kachlík D, Čech P. České anatomické názvosloví [on the Internet]. Praha; Ústav anatomie 3. LF UK; c2004. [cited 2008 Aug 18]. Available from: www.anatomickenazvoslovi.cz.

25. Rosse C. Terminologia Anatomica. Considered From the Perspective of Next-Generation Knowledge Sources. Clin Anat 2001; 14:120-33.

26. Whitmore I. Terminologia anatomica: new terminology for the new anatomist. Anat Rec 1999; 257:50-3.

27. Greathouse DG, Halle JS, Dalley AF. Terminologia Anatomica: Revised Anatomical Terminology. J Orthop Sports Phys Ther 2004; 34:363-7.

28. Drukker J. Terminologia anatomica, the new reference for anatomical nomenclature. Eur J Morphol 2000; 38:279-80.

29. Čihák R. Anatomie. Díl 1. 2. upr. a dopl. vyd. Praha: Grada; 2001.

30. Čihák R. Anatomie. Díl 2. 2. upr. a dopl. vyd. Praha: Grada; 2002.

31. Čihák R. Anatomie. Díl 3. 1. vyd. Praha: Grada; 1997.

32. Daubner W. Feneisův obrazový slovník anatomie. Praha: Grada Publishing; 2007.

33. Grim M, Druga R et al. Základy anatomie. 1., Obecná anatomie a pohybový systém. Praha: Karolinum, Galén; c2001.

34. Grim M, Druga R et al. Základy anatomie. 3., Trávicí, dýchací, močopohlavní a endokrinní systém. Praha: Karolinum, Galén; c2005.

35. Grim M, Druga R et al. Základy anatomie. 5., Anatomie krajin těla. Praha: Karolinum, Galén; 2001.

36. Petrovický P. Anatomie s topografií a klinickými aplikacemi. I. svazek, Pohybové ústrojí. Martin: Osveta; 2001.

37. Petrovický P. Anatomie s topografií a klinickými aplikacemi. II. svazek, Orgány a cévy. Martin: Osveta; 2001.

38. Petrovický P. Anatomie s topografií a klinickými aplikacemi. III. svazek, Neuroanatomie, smyslová ústrojí. Martin: Osveta; 2002. 
